\begin{tabular}{|c|c|c|}
\hline & Int.J.Curr.Microbiol.App.Sci (2016) 5(3): 610-616 & \\
\hline & International Journal of Current Microbiology and Applied Sciences & 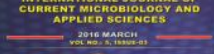 \\
\hline & ISSN: 2319-7706 Volume 5 Number 3(2016) pp. 610-616 & \\
\hline EXCELLENT & Journal homepage: http://www.ijcmas.com & \\
\hline PUBLISHERS & & Inwwi.jemas con \\
\hline
\end{tabular}

Original Research Article

http://dx.doi.org/10.20546/ijcmas.2016.503.071

\title{
Response of Integrated Weed Management Practices on Growth and Yield of Pigeonpea (Cajanus cajan (L.) Millsp.)
}

\author{
A. Subbarami Reddy ${ }^{*}$, P.Venkata Rao, J.Sateesh Babu and Y.Koteswara Rao \\ Regional Agricultural Research Station, ANGRAU, Lam-522034, Guntur, AP, India \\ *Corresponding author
}

Keywords

Pigeonpea,

IWM, weeds, weed control efficiency, hand weeding

Article Info

Accepted:

20 February 2016

Available Online:

10 March 2016

\author{
A B S T R A C T
}

The field experiment was conducted during kharif (rainy) seasons of 2011 and 2012 at Regional Agricultural Research Station, Lam, Guntur, India in randomized block design with three replications to study the response of integrated weed management (IWM) practices on growth and yield of pigeonpea. The weed free treatment significantly decreased the weed density, dry weight of weeds and also increased in weed control efficiency compared with weedy check. Integration of one hand weeding/intercultivation at 50 DAS with application of imazathapyr @ 75 $\mathrm{g}$ a.i./ha at 10-15 DAS+quizalofop-ethyl @ 50g a.i./ha proved effective in reducing total weed density and dry weights of weeds and also increased in weed control efficiency compared with weedy check. The maximum values of growth parameters, yield attributes and yield (1934 kg/ha) were recorded under weed free situation but it was significantly superior over all other treatments. Among the IWM practices, application of imazethapyr @75g a.i./ha at 10-15 DAS+ quizalofop-ethyl @50g a.i./ha at 15 DAS followed by one hand weeding/intercultivation at 50 DAS resulted the maximum yield $(1707 \mathrm{~kg} / \mathrm{ha})$ which was closely followed by application of Pendimethalin @ 0.75g a.i./ha PE+ Imazethapyr @ $60 \mathrm{~g}$ a.i./ha POE at 15 DAS $(1509 \mathrm{~kg} / \mathrm{ha})$ than weedy check $(949$ $\mathrm{kg} / \mathrm{ha}$ ). Beneficial effect due to above treatments on growth characters resulted in enhanced grain yields of pigeonpea.

\section{Introduction}

Pigeonpea (Cajanus cajan (L.) Millsp.) commonly known as red gram, tur or arhar is the fifth prominent legume crop in the world. India, Myammar, Malawi, Kenya, Uganda and Tanzania are the major pigeonpea producing countries. It has been recognized as a valuable source of protein for the vegetarians in their daily diet. In India, pigeonpea is second most important pulse crop of India which has diversified uses as food, feed, fodder and fuel, next to Chickpea producing 3.29 million tons annually from 3.88 million ha (Anon, 2013). The Indian sub continent alone contributes nearly 92 per cent of the total pigeonpea production in the world. Although India leads the world both in area and production of pigeonpea, its productivity is lower (697 $\mathrm{kg} / \mathrm{ha})$ than the world average $(775 \mathrm{~kg} / \mathrm{ha})$ (FAO, 2013). 
In India, pigeonpea is grown in kharif season. Due to rainy season, slow initial growth and sowing at wider spacing, severe infestation of weeds was observed in pigeonpea which results in low grain yield. Crop yield losses due to weeds have been estimated to range from 55 to $60 \%$ has been reported (Kandasamy, 1999). However, due to frequent rains it becomes difficult to hand weeding at proper time. Furthermore, non availability of labour for hand weeding is another problem. So it is very necessary to find out effective weed control techniques using herbicides. The predominant method of weed control by mechanical hoeing and manual weeding over extensive scale is found to decline because of shift of agricultural labourers to industries for better and assured wages. In pigeonpea, initial sixseven weeks period (42-49 days) is the critical period of crop-weed competition. Therefore, weeds must be controlled during this period for realising higher grain yields. Pre-emergence application of herbicides may help in checking weed growth during this period. Pendimethalin, as preemergence herbicide, has been found effective in controlling weeds and improving pigeonpea yield (Reddy et al., 2007).

However, it is effective only up to one month and thereafter weeds may pose a problem again. Therefore, the use of herbicides alone or in combination with other weed control techniques reduces the crop weed competition and the risk of weeds growing unchecked in period of adverse weather. The integrated weed management approach is advantageous because one technique rarely achieve complete long and effective control of all weeds during crop season. Integrated use of pendimethalin with hand weeding or ridging may help in achieving season long weed control. Integrated weed management provides effective and efficient weed management in pigeonpea (Reddy et al., 2007; Sukhadia et al., 2000 and Tomar et al., 2004) and cowpea (Madukwe et al., 2012).

Sometimes, farmers miss the application of pre-emergence herbicide and later on find it very difficult to control weeds manually. Under such situations, post-emergence application of herbicides may help in alleviating weed problem. Some of the herbicides may be phytotoxic to pigeonpea at higher rate of application (Kandasamy, 1999 and Semidey, 2002) or to the succeeding crop (Bidlack et al., 2006). Therefore, the present investigation was undertaken to provide appropriate options to farmers for effective weed management in kharif pigeonpea.

\section{Materials and Methods}

Field experiments was conducted during kharif (rainy) season 2011 and 2012 at RARS, Lam, Guntur, India to find out the response of integrated weed management practices on growth and yield of pigeonpea. The soil of the experimental site was clay loam in texture with soil $\mathrm{pH}$ was neutral in reaction (6.2) and an electrical conductivity of $0.22 \mathrm{dSm}^{-1}$. The soil organic carbon content was low $(0.51 \%)$. The soil was low in available nitrogen $\left(223 \mathrm{~kg} \mathrm{ha}^{-1}\right)$, medium in available phosphorus (23.4 $\left.\mathrm{kg} \mathrm{ha}^{-1}\right)$ and available potassium $\left(312 \mathrm{~kg} \mathrm{ha}^{-1}\right)$. The total rainfall received during crop growth period was $1060.9 \mathrm{~mm}$ in 59 rainy days. Seeds of pigeonpea variety LRG-41 were sown on $14^{\text {th }}$ July, 2013 by dibbling method. Recommended dose of fertilizers $20 \mathrm{~kg} \mathrm{~N}$ and $50 \mathrm{~kg} \mathrm{P}_{2} \mathrm{O}_{5} /$ ha was applied through urea and single super phosphate (SSP) before dibbling.

The details of the treatments $\mathrm{T}_{1}$ : weedy check $\mathrm{T}_{2}$ : Pendimethalin @ $0.75 \mathrm{~kg} / \mathrm{ha} \mathrm{PE}+$ 
1 hand weeding at $50 \mathrm{DAS} /$ Intercultivation; $\mathrm{T}_{3}$ : EPOE Imazethapyr @75 g a.i./ha at 1015 DAS+ 1 hand weeding at 50 DAS/Intercultivation; $\mathrm{T}_{4}$ : Imazethapyr @ 75g a.i./ha at 10-15 DAS+ Quizalofop ethyl @ $50 \mathrm{~g}$ a.i./ha POE AT 15 das; $\mathrm{T}_{5}$ : Tank mix application of Imazethapyr @ $75 \mathrm{~g}$ a.i./ha + Quizalofop ethyl @ $50 \mathrm{~g}$ a.i./ha POE at 15 DAS; T : Imazethapyr @ $75 \mathrm{~g}$ a.i./ha + Quizalofop ethyl @ $50 \mathrm{~g}$ a.i./ha POE at 15 DAS +1 hand weeding at 50 DAS/Intercultivation; $\mathrm{T}_{7}$ : Tank mix application of Imazethapyr @ $75 \mathrm{~g}$ a.i./ha + Quizalofop ethyl @ $50 \mathrm{~g}$ a.i./ha POE at 15 DAS+ 1 hand weeding at 50 DAS/ Intercultivation; $\mathrm{T}_{8}$ : Pendimethalin @0.75g a.i./ha PE+ Imazethapyr @ $60 \mathrm{~g}$ a.i./ha POE at $15 \mathrm{DAS}$ and $\mathrm{T}_{9}$ :Weed free were tested in randomized block design (RBD). In case of weed free treatment, two hand weedings at 25 DAS and 50 DAS manually using hand operated small implements. In case of pendimethalin treatments, the weedicide was sprayed on the same day after sowing using knapsack sprayer fitted with flood jet nozzle and the spay fluid was 500 litres per hectare. In case of quizalofop ethyl and imazathapyr were sprayed as postemergence application at 10-15 DAS with a spray volume of 500 litres per hectare. Spraying was done by manually operated Knapsack sprayer. Then hand weeding and intercultivation operations were carried out after weedicide application as per treatments. The crop was grown with standard packages of practices for the region.

Plant height at harvest was recorded for randomly selected five plants. The weed counts were recorded by using quadrant at 70 DAS and kept in hot air oven for recording dry weights. Grain yield data was recorded on whole plot basis and then converted in to $\mathrm{kg} \mathrm{ha}^{-1}$. Data on yield components viz., branches per plant, pods plant $^{-1}$ and test weight (100 grain) was also recorded. All data were subjected to analysis of variance (ANOVA) as per standard procedures. Whenever ' $F$ ' ratio was found significant, critical difference (CD) value was calculated at $\mathrm{p}=0.05$ to compare the treatment means.

\section{Results and Discussion}

\section{Effect on Weeds}

The predominant weeds found in the experimental plots were broad leaf weeds such as Euphorbia hirta, Digera arvensis, Trianthima portulcastrum, Phyllanthus niruri, Boerhavia diffusa, Cleome viscosa, Parthenium hysterophorus, grassy weeds such as Cynodon doctylon, Eleusine aegyptiacum and sedge Cyperus rotundus. The experimental findings regarding integrated weed management practices on growth, yield attributes, yield of pigeonpea under rainfed condition during kharif seasons and on weed growth is given in Table 1and 2. It was observed that the maximum weed intensity and weed dry weight in weedy check were significantly more as compared to rest of the treatments in both the years of investigation. The lowest weed counts/intensity and weed dry weights were observed in weed free treatment. The dry matter of weeds in weedy check was the maximum because of higher weed intensity and its dominance in utilizing the sunlight, nutrients, moisture, $\mathrm{CO}_{2}$ etc. These results are in close conformity with those of Dhonde et al.(2009) and Idupuganti et al.(2005).

Unweeded control plot, as expected, recorded the highest dry matter of weeds, which was reduced drastically by all other treatments (Table 1). Among the herbicide treatments, post-emergence application of imazathapyr @75 g a.i./ha + quizalofopethyl @ 50g a.i./ha followed by one hand weeding/intercultivation at $50 \operatorname{DAS}\left(T_{8}\right)$ 
resulted in excellent control of monocot and dicot weeds than without integration of hand weeding/intercultivation $\left(\mathrm{T}_{4}\right)$. The highest weed counts and dry matter were recorded in weedy check plot than that of remaining treatments. Higher weed control efficiency (WCE) and long lasting effects of imazethapyrin reducing weed dry matter might be due to broad spectrum activity of herbicides particularly on established plants of both narrow and broad leaf weeds and its greater efficiency to retard cell division of meristems as a result of which weeds dried rapidly. This integrated use of herbicide(s) followed by hand weeding/intercultivation (at 50 DAS) results effective weed control (Singh and Sekhon, 2013 and Venkata Rao et al., 2015).

Data regarding weed control efficiency
(WCE) as influenced by various weed control treatments, revealed that at 70 DAS, the maximum WCE was due to weed free treatment i.e. 100 per cent which was superior to those observed in rest of the treatments. Imazathapyr @ $75 \mathrm{~g}$ a.i./ha POE at 10-15 DAS + Quizalofop-ethyl @ 50 g a.i.ha - POE at 15DAS in integration with one hand weeding/intercultivation at 50 DAS $\left(\mathrm{T}_{6}\right)$ resulted in the highest weed control efficiency (WCE) (82.8\%) followed by $\mathrm{T}_{7}$ (tank mix application of Imazathapyr@75 a.i./ha at 10-15 DAS +quizalofop-ethyl @50g a.i. /ha at 10-15 DAS and in integration with one hand weeding/intercultivation at 50 DAS) $(80.3 \%)$ and $\mathrm{T}_{5}$ (tank mix application of Imazathapyr@75 a.i./ha at 10-15 DAS +quizalofop-ethyl @50g a.i. /ha at 10-15 DAS) $(74.3 \%)$.

Table.1 Effect of integrated weed control practices on growth and weeds in Pigeonpea

\begin{tabular}{|c|c|c|c|c|c|c|c|c|c|c|c|c|}
\hline \multirow{2}{*}{ Treatments } & \multicolumn{3}{|c|}{ Plant ht. $(\mathrm{cm})$ at harvest } & \multicolumn{3}{|c|}{ Weed counts $\left(\right.$ No. $\left./ \mathrm{m}^{2}\right)$} & \multicolumn{3}{|c|}{ Weed dry wt. $\left(\mathrm{g} / \mathrm{m}^{2}\right)$} & \multicolumn{3}{|c|}{ WCE $(\%)$} \\
\hline & 2011 & 2012 & Mean & 2011 & 2012 & Mean & 2011 & 2012 & Mean & 2011 & 2012 & Mean \\
\hline $\mathbf{T}_{1}$ & 140 & 183 & 162 & 237 & 178 & 208 & 57.0 & 63.7 & 60.4 & - & - & - \\
\hline $\mathbf{T}_{2}$ & 178 & 174 & 176 & 105 & 79 & 92 & 16.7 & 18.3 & 17.5 & 70.7 & 71.3 & 71.0 \\
\hline $\mathbf{T}_{3}$ & 174 & 183 & 179 & 132 & 99 & 116 & 15.0 & 17.3 & 16.2 & 73.7 & 72.8 & 73.3 \\
\hline $\mathbf{T}_{4}$ & 196 & 205 & 201 & 76 & 57 & 67 & 16.3 & 16.7 & 16.5 & 71.4 & 74.1 & 72.9 \\
\hline $\mathbf{T}_{5}$ & 165 & 184 & 175 & 95 & 71 & 83 & 14.7 & 18.0 & 16.4 & 74.2 & 74.3 & 74.3 \\
\hline$T_{6}$ & 196 & 227 & 212 & 64 & 48 & 56 & 11.0 & 9.7 & 10.4 & 80.7 & 84.8 & 82.8 \\
\hline $\mathbf{T}_{7}$ & 163 & 201 & 182 & 104 & 78 & 91 & 12.0 & 11.7 & 11.9 & 78.9 & 81.6 & 80.3 \\
\hline $\mathbf{T}_{8}$ & 176 & 237 & 207 & 181 & 136 & 159 & 17.7 & 16.0 & 16.9 & 71.9 & 74.9 & 73.4 \\
\hline$T_{9}$ & 193 & 225 & 209 & 0.0 & 0.0 & 0.0 & 0.0 & 0.0 & 0.0 & 100.0 & 100.0 & 100.0 \\
\hline $\mathrm{SEM}_{\underline{ \pm}}$ & 8.8 & 14.6 & - & 12.8 & 9.6 & - & 1.67 & 1.87 & - & - & - & - \\
\hline $\mathrm{CD}(5 \%)$ & 26.3 & NS & - & 38 & 29 & - & 5.0 & 5.6 & - & - & - & - \\
\hline
\end{tabular}

$\mathrm{T}_{1^{-}}$Weedy check, $\mathrm{T}_{2^{-}}$Pendimethalin @ 0.75kg/ha-PE+ one HW at 50DAS/Intercutivation, $\mathrm{T}_{3^{-}}$EPOEImazathapyr@75 $\mathrm{g}$ a.i./ha at 10-15 DAS+ one $\mathrm{HW}$ at 50DAS/Intercutivation, T $4^{-}$Imazathapyr@75g a.i./ha at 10-15 DAS+ Quizalofop-ethyl @ $50 \mathrm{~g}$ a.i. /ha - POE at 15DAS, $\mathrm{T}_{5^{-}}$Tank mix application of Imazathapyr@75 g a.i./ha + Quizalofop-ethyl @ $50 \mathrm{~g}$ a.i./ha - POE at 15DAS, T6- Imazathapyr@75g a.i./ha at 10-15 DAS+ Quizalofop-ethyl @ $50 \mathrm{~g}$ a.i. /ha - POE at 15DAS+ one $\mathrm{HW}$ at 50DAS/Intercutivation, $\mathrm{T}_{7^{-}}$Tank mix application of Imazathapyr@75 g a.i./ha + Quizalofop-ethyl @ 50 g a.i./ha-POE at 15DAS+ one HW at 50DAS/Intercutivation, $\quad \mathrm{T}_{8}$ Pendimethalin $0.75 \mathrm{~kg} / \mathrm{ha}$ pre- + Imazathapyr @ 60g a.i./ha at 10-15 DAS, T9-Weed free. 
Table.2 Effect of integrated weed control practices on yield attributes and grain yield in Pigeonpea

\begin{tabular}{|c|c|c|c|c|c|c|c|c|c|c|c|c|}
\hline \multirow{2}{*}{ Treatments } & \multicolumn{3}{|c|}{ Branches plant $^{-1}$} & \multicolumn{3}{|c|}{ Pods plant $^{-1}$} & \multicolumn{3}{c|}{ Test weight $(\mathrm{g})$} & \multicolumn{3}{c|}{ Grain Yield (kg/ha) } \\
\cline { 2 - 14 } & 2011 & 2012 & Mean & 2011 & 2012 & Mean & 2011 & 2012 & Mean & 2011 & 2012 & Pooled \\
\hline $\mathbf{T}_{\mathbf{1}}$ & 18.3 & 13.0 & 15.7 & 126 & 124 & 125 & 9.8 & 10.8 & 10.3 & 530 & 1367 & 949 \\
\hline $\mathbf{T}_{\mathbf{2}}$ & 21.7 & 15.0 & 18.4 & 185 & 144 & 165 & 11.0 & 11.8 & 11.4 & 1000 & 1517 & 1259 \\
\hline $\mathbf{T}_{\mathbf{3}}$ & 21.8 & 10.3 & 16.1 & 189 & 161 & 175 & 10.9 & 12.1 & 11.5 & 864 & 1533 & 1199 \\
\hline $\mathbf{T}_{\mathbf{4}}$ & 23.1 & 14.0 & 18.6 & 188 & 171 & 180 & 10.9 & 12.2 & 11.6 & 1214 & 1583 & 1399 \\
\hline $\mathbf{T}_{\mathbf{5}}$ & 19.9 & 15.3 & 17.6 & 172 & 132 & 152 & 10.6 & 12.3 & 11.5 & 1031 & 1690 & 1361 \\
\hline $\mathbf{T}_{\mathbf{6}}$ & 23.6 & 16.7 & 20.2 & 224 & 262 & 243 & 11.9 & 12.6 & 12.3 & 1281 & 2133 & 1707 \\
\hline $\mathbf{T}_{\mathbf{7}}$ & 19.5 & 16.7 & 18.1 & 134 & 197 & 166 & 10.1 & 10.7 & 10.4 & 997 & 1469 & 1233 \\
\hline $\mathbf{T}_{\mathbf{8}}$ & 23.3 & 15.3 & 19.3 & 192 & 187 & 190 & 11.8 & 11.8 & 11.8 & 1065 & 1952 & 1509 \\
\hline $\mathbf{T}_{\mathbf{9}}$ & 23.3 & 19.3 & 21.3 & 230 & 282 & 256 & 12.0 & 14.7 & 13.4 & 1387 & 2481 & 1934 \\
\hline SEM $\mathbf{\pm}$ & 1.0 & 1.3 & - & 12 & 17.6 & - & 0.5 & 0.7 & - & 58.7 & 91.6 & 66.9 \\
\hline $\mathrm{CD}(5 \%)$ & 3.0 & 4.1 & - & 37 & 53 & - & 1.4 & 2.1 & - & 176 & 276 & 200 \\
\hline
\end{tabular}

$\mathrm{T}_{1^{-}}$Weedy check, $\mathrm{T}_{2^{-}}$Pendimethalin @ 0.75kg/ha-PE+ one $\mathrm{HW}$ at 50DAS/Intercutivation,

$\mathrm{T}_{3^{-}}$EPOEImazathapyr@75 g a.i./ha at 10-15 DAS+ one $\mathrm{HW}$ at 50DAS/Intercutivation,

$\mathrm{T}_{4}$ - Imazathapyr@75g a.i./ha at 10-15 DAS+ Quizalofop-ethyl @ $50 \mathrm{~g}$ a.i. /ha - POE at 15DAS,

$\mathrm{T}_{5^{-}}$Tank mix application of Imazathapyr@75 g a.i./ha + Quizalofop-ethyl @ $50 \mathrm{~g}$ a.i./ha - POE at 15DAS, T $6^{-}$Imazathapyr@75g a.i./ha at 10-15 DAS+ Quizalofop-ethyl @ $50 \mathrm{~g}$ a.i. /ha - POE at 15DAS+ one $\mathrm{HW}$ at 50DAS/Intercutivation, $\mathrm{T}_{7-}$ Tank mix application of Imazathapyr@75 $\mathrm{g}$ a.i./ha + Quizalofop-ethyl @ $50 \mathrm{~g}$ a.i. /ha - POE at 15DAS+ one HW at 50DAS/Intercutivation, $\quad \mathrm{T}_{8^{-}}$ Pendimethalin $0.75 \mathrm{~kg} / \mathrm{ha}$ pre- + Imazathapyr @ 60g a.i./ha at 10-15 DAS, $\mathrm{T}_{9}$-Weed free.

Integration of hand weeding /intercultivation at 50 DAS with Pendimethalin@ $1.0 \mathrm{~kg} / \mathrm{ha}$ PE or EPOE Imazathapyr @ $75 \mathrm{~g}$ a.i./ha POE at 10-15 DAS $\left(\mathrm{T}_{3}\right)$ proved effective than without integration of hand weeding/intercultivation at 50 DAS. This might be due to the efficient control of dicot weeds by hand weeding and /interculturing along with application of herbicides. Similar results of high WCE in urdbean (Gupta et al.,2014), soybean (Sharma et al.,2014) and pigeonpea (Venkata Rao et al., 2015) was reported from Jammu, Rajasthan and Lam (AP), respectively.

\section{Effect on crop}

The maximum plant height $(212 \mathrm{~cm})$ was recorded in treatment $\mathrm{T}_{6}$ but it was closely followed by $\mathrm{T}_{4}(201 \mathrm{~cm}), \mathrm{T}_{8}(207 \mathrm{~cm})$ and $\mathrm{T}_{9}$ treatments $(209 \mathrm{~cm})$, however, all these IWM practices superior over weedy check
(162 cm). Similarly, the highest yield attributes, viz. more number of branches per plant (21.3), pods per plant (256) and test weight $(13.4 \mathrm{~g})$ were recorded in weed free treatment and these values higher than other cultural and herbicide treatments including weedy check. Data pertaining to pods plant ${ }^{-1}$ and test weight revealed that weed free and herbicides alone or in combination of intercultivation/HW at 50 DAS had significant effect on both parameters. Among the herbicides alone or integration of intercultivation/hand weeding at 50DAS with herbicides, $\mathrm{T}_{6}$ recorded the highest values of pods plant ${ }^{-1}$ (243) and test weight $(12.3 \mathrm{~g})$ followed by $\mathrm{T}_{8}(190$ and $11.8 \mathrm{~g}$, respectively) and $\mathrm{T}_{4}(180$ and $11.6 \mathrm{~g}$, respectively).It can be stated from the above findings that, though pods plant ${ }^{-1}$ and 100 seed weight are varietal characters but tremendous weed infestation caused stress to the crop plants with respect to nutrients, 
moisture, sunlight, space and other various aspects related to physiological processes of crop plants and these enforced the crop to have less number of pods plant $^{-1}$ and test weight and this was highly evident in weedy check treatment (Meena et al., 2010).

The maximum grain yield (1934 kg/ha) was obtained with weed free treatment which was significantly superior than weedy check (949 kg/ha) and remaining other treatments . The lower grain yields were recorded with treatment weedy check $(949 \mathrm{~kg} / \mathrm{ha})$ due to appearance of weeds since beginning of crop emergence and resulted in great competition with crop plants for nutrients, moisture and/ sunlight. Similar grain yield losses due to weeds were reported in kharif pigeonpea (Meena et al., 2010 and Venkata Rao et al., 2015). However, amongst the set of IWM treatments, the maximum grain yield was recorded under IWM treatments viz., integration of one hand weeding/ intercultivation at 50DAS with imazathapyr @ $75 \mathrm{~g}$ a.i./ha + quizalofop ethyl @ $50 \mathrm{~g}$ a.i./ha as POE at 10-15 DAS (1707 kg/ha) which was closely followed by $\mathrm{T}_{8}$ treatment $(1509 \mathrm{~kg} / \mathrm{ha})$. Higher grain yields in these treatments may be due to effective weed control as reflected in lower weed dry matter, higher WCE, better plant growth and yield attributes (Table 2).With integration of one hand weeding/intercultivation at 50DAS with application of imazathapyr @ $75 \mathrm{~g}$ a.i./ha + quizalofop ethyl @ $50 \mathrm{~g}$ a.i./ha as POE at 10-15 DAS proved better than other treatments. It can be explained in the light of the facts that these treatments controlled the weeds effectively, might have made more nutrients available to crop and consequently encouraged higher concentration of nutrients and more yields. This variation in weed control could be due to infestation of various weed species and climatic conditions including rainfall distribution pattern. These findings are in concurrence with those of
(Idupuganti et al., 2005; Sharma et al.,2014; Murali et al., 2013 and Venkata Rao et al., 2015).

In conclusion, from this study, it can be concluded that weed control is a limited factor for realizing higher grain yields in pigeonpea. Apart from the weed free treatment, weeds can also be effectively and efficiently controlled with integration of imazathapyr @75 g a.i./ha + quizalofop ethyl @ $50 \mathrm{~g}$ a.i./ha as POE at 10-15 DAS followed by hand weeding/intercultivation at 50 DAS which ultimately results in higher grain yields of pigeonpea.

\section{References}

Anonymous, 2013.

Bidlack, J.E., Middick, A., Shantz, D., MacKown, C.T., Williams, R.D., and Rao, S.C. 2006. Weed control in a pigeon pea-wheat cropping system. Field Crops Research, 96(1): 63-70.

Dhonde, M.B., Kate, S.R., Pandure, B.S., and Tambe, A.D. 2009.Integrated weed management in pigeonpea. Indian Journal of Weed Science, 41(1\&2) : 102-105

FAOSTAT, 2013. http://faostat.fao.org.

Gupta, V., Singh, M., Kumar, A., Sharma, B. C., and Kher, D. 2014. Effect of different weed management practices in urdbean (Vigna mungo L. Hepper) under sub-tropical rainfed conditions of Jammu, India. Legume Research: An International Journal, 37 (4):424-426.

Idapuganti, R.G., Rana, D.S., and Sharma, R. 2005. Influence of integrated weed management on weed control and productivity of soybean [Glycine max (L.) Merrill]. Indian Journal of Weed Science, 37 (1/2): 126-128.

Kandasamy, O.S. 1999. Effect of herbicide with and without manual weeding on weed and yield of rainfed pigeonpea 
(Cajanus cajan). Legume Research, 22 (3): 172-176.

Madukwe, D. K., Ogbuehi, H.C., and Onuh, M.O. 2012.Effects of weed control methods on growth and yield of cowpea ( vigna ungiculata(L.) Walp) under rainfed conditions of Owerri. American-Eurasian Journal of Agriculture and Environmental Sciences, 12 (11): 1426-1430.

Meena Babulal, Sagarka, B.K., and Pisal, R.R. 2010.Efficacy of new herbicides in kharif pigeonpea under south Saurashtra condition. Indian Journal of Weed Science, 42(1\&2): 98-100.

Murali, K., Mallesha, and Fakeerappa Arabhanvi. 2013. Effect of integrated weed management practices on growth, yield and weed dry weight of pigeonpea. Ecology, Environment and Conservation, 19 (4): 1279-1283.

Reddy, M.M., Vilatha, and A.M., Rao, L.J. 2007. Integrated weed management in pigeonpea (Cajanus cajan)-soybean (Glycine max) intercropping system on Vertisol under rainfed conditions. Indian Journal of Agricultural Sciences, 77(3): 177-178.

Semidey, N. 2002. Response of pigeonpea cultivars to prometryn, metribuzin and imazethapyr. Journal of Agriculture of the University of Puerto Rico, 86 (1/2): 69-71.
Sharma, J. C., Chandra Prakash, Shivran, R. K., and Narolia, R. S. 2014.Integrated weed management in pigeonpea (Cajanus cajan (L.) Millsp.). IJAAS. 2 (1-2): 69-74.

Singh, G. and Sekhon, H.S. 2013. Integrated Weed Management in Pigeonpea (Cajanus cajan (L.) Millsp.). World Journal of Agricultural Sciences, 9 (1): 86-91.

Sukhadia, N.M., Ramani, B.B., Modhwadia, M.M., and Asodaria, K.B. 2000. Integrated weed management in pigeonpea (Cajanus cajan L. Millsp.). Gujarat Agricultural University Research Journal, 25(2): 1-4.

Tomar, J., Singh, H.B., Vivek,S.S., and Tripathi, S.S. 2004. Integrated weed management in intercropping of mungbean (Vigna radiata) and cowpea fodder (Vigna unguiculata) with pigeonpea (Cajanus cajan) under western U. P. condition. Indian Journal of Weed Science, , 36(1/2): 133-134.

Venkata Rao, P., Subbarami Reddy, A and Koteswara Rao,Y. 2015. Effect of integrated weed management practices on growth and yield of pigeonpea (Cajanus cajan (1.) Millsp.). International Journal of Plant, Animal and Environmental Sciences, 5(3):124127.

\section{How to cite this article:}

Subbarami Reddy, A., P.Venkata Rao, J.Sateesh Babu and Koteswara Rao, Y. 2016. Response of Integrated Weed Management Practices on Growth and Yield of Pigeonpea (Cajanus cajan (L.) Millsp.). Int.J.Curr.Microbiol.App.Sci. 5(3): 610-616. doi: http://dx.doi.org/10.20546/ijcmas.2016.503.071 